\title{
Suicidal ideation and suicide attempts in subjects aged 15-19 in Lomé (Togo)
}

\author{
Tchin Darré ${ }^{*}$, Koffi Assaba Cinthia Consuela' ${ }^{1}$ Bayaki Saka², Toukilnan Djiwa' ${ }^{1}$, Koumavi Didier Ekouévi ${ }^{3}$ \\ and Gado Napo-Koura ${ }^{1}$
}

\begin{abstract}
Objectives: The purpose of this study was to study the epidemiological and clinical profile of adolescents with suicidal thoughts, with or without suicide attempts, and to identify associated factors.

Results: A total of 155 (16.5\%) of the 941 adolescents interviewed had suicidal thoughts. The average age of the respondents was $18 \pm 2.1$ years. The sex ratio $(\mathrm{m} / \mathrm{f})$ was 1.4 . With regard to marital status, $70.2 \%$ were single and $29.8 \%$ were in a relationship with a cohabiting partner. Family history of suicide was reported in $40 \%$. In their personal history, eight were infected with HIV, three were chronic ethylic and two were diabetics. Forty-six (29.7\%) of the 155 adolescents who had suicidal ideation had ever had a suicide attempt. Teens affected by suicide lived in a boarding school in $25.8 \%$, with one parent in $23.9 \%$ and $50.3 \%$ with both parents. Factors associated with suicide attempts were female sex $(p=0.0107)$, age over 18 years $(p=0.0177)$, living in a couple $(p=0.0316)$, underlying immunodepression (HIV infection, $p=0.0059$, sickle cell disease, $p=0.0043$ ) and having a family history of suicides $(p=0.0461)$.
\end{abstract}

Keywords: Suicides, Adolescents, Lomé (Togo)

\section{Introduction}

Worldwide, suicide is a common cause of death among young people, which is a major public health problem. It is the second leading cause of death after road accidents among young people aged 15-19 in Western countries $[1,2]$. Adolescence is a period more likely to lead to suicidal behavior [3]. It is important to know that this is an intense period of social, family, physical and emotional change [4]. In sub-Saharan Africa in general, and in Togo in particular, suicide attempts remain a poorly evaluated subject due to socio-cultural considerations and lack of a longitudinal approach $[4,5]$. The objective of this study was to determine the prevalence and to study the sociodemographic and clinical characteristics of adolescents with suicidal ideation and suicide attempts in the adolescent population of Lomé (Togo).

\footnotetext{
*Correspondence: paolodarre@yahoo.fr

1 Department of Pathology, University of Lomé, B.P. 1515 Lome, Togo

Full list of author information is available at the end of the article
}

\section{Main text \\ Methodology}

It was a descriptive cross-sectional study conducted among adolescents aged 15-19 enrolled in high schools in the city of Lomé and at the University of Lomé. It took place from March to June 2018 for duration of 3 months. Included were adolescents aged between 15 and 19 years enrolled in high schools in the city of Lomé and students aged 15-19 enrolled during the academic year 20172018 at the University of Lomé. The variables studied were: socio-demographic variables, motives for ideas and suicide attempts, means of suicide attempts.

The data was recorded on the Epidata 3.1 software. The data analysis was done on the software $\mathrm{R}$ in version 3.4.3. For the descriptive analysis, the quantitative variables were presented as mean and standard deviation and the qualitative variables as numbers and percentages. For the comparative analysis and the univariate analysis the threshold of significance was 0.05 . The statistical tests used for the comparative analysis were the Chi-2 or Fisher test for the comparison of two qualitative variables and the Student's test for the comparison of two means. 


\section{Results}

During this period, 941 teenagers accepted the questionnaire, 602 high school students and 339 students. Of these, 155 (16.5\%) had suicidal thoughts. The average age of the subjects was 17.5 years and the sex ratio $(\mathrm{M} / \mathrm{F})$ was 1.4. Subjects with suicidal thoughts were high school students and secondary school students in 51.6\% and $48.4 \%$ respectively. With regard to marital status, $71 \%(\mathrm{n}=106)$ were single, $28 \%(n=43)$ were married couples with one partner and $1 \%(n=2)$. The epidemiological data of adolescents with idea and attempted suicide are summarized in Table 1 . The revelation of the intention to commit suicide was noted in 61 subjects (39.4\%), of which 56 subjects to close and 5 subjects to a doctor. Family history of suicide in at least one parent was observed in $25.8 \%$ $(\mathrm{n}=40)$. One hundred and one parents $(65.2 \%)$ for whom we have information concerning their socio-economic conditions was of categories: weak in 49 cases, average in 41 and high in 11 cases. Forty-six (31 girls and 15 boys) or $29.7 \%$ of the subjects had already attempted suicide. The suicide idea/suicide attempt report was 3.4. Of his 46

Table 1 Epidemiological characteristics of adolescents

\begin{tabular}{|c|c|c|c|c|c|}
\hline \multirow[t]{2}{*}{ Characteristics } & \multicolumn{5}{|c|}{ Univariate model } \\
\hline & $n / N$ & $\%$ & OR & $\mathrm{Cl} 95 \%$ & $p$ value \\
\hline Sex & & & & & 0.0107 \\
\hline Male & $12 / 65$ & 18.5 & 1 & & \\
\hline Female & $34 / 90$ & 37.8 & 2.68 & {$[1.28-5.90]$} & \\
\hline Median age (years) & & & & & 0.0177 \\
\hline$<18$ & $15 / 72$ & 20.8 & 1 & & \\
\hline$\geq 18$ & $31 / 80$ & 38.8 & 2.40 & {$[1.18-5.06]$} & \\
\hline Level of study & & & & & 0.6108 \\
\hline University & $5 / 20$ & 25.00 & 1 & & \\
\hline Secondary & $41 / 134$ & 30.60 & 1.32 & {$[0.48-4.28]$} & \\
\hline Marital status & & & & & 0.0316 \\
\hline Single & $26 / 106$ & 24.5 & 1 & & \\
\hline Married & $19 / 45$ & 42.2 & 2.25 & {$[1.07-4.72]$} & \\
\hline $\begin{array}{l}\text { Underlying immunode- } \\
\text { pression }\end{array}$ & & & & & 0.0059 \\
\hline No & $33 / 131$ & 25.2 & 1 & & \\
\hline Yes & $13 / 24$ & 54.2 & 3.51 & {$[1.44-8.74]$} & \\
\hline Sickles cells disease & & & & & 0.0043 \\
\hline No & $38 / 144$ & 26.4 & 1 & & \\
\hline Yes & $8 / 11$ & 72.7 & 7.44 & {$[2.04-35.31]$} & \\
\hline Live with family & & & & & 0.2327 \\
\hline Intership & $14 / 38$ & 36.84 & 1 & & \\
\hline Two parents & $24 / 77$ & 31.17 & 0.78 & {$[0.34-1.78]$} & 0.5434 \\
\hline Only one of the two & $8 / 40$ & 20.00 & 0.43 & {$[0.15-1.16]$} & 0.1026 \\
\hline Family history of suicide & & & & & 0.0461 \\
\hline No & $22 / 93$ & 23.66 & 1 & & \\
\hline Yes & $24 / 62$ & 38.71 & 2.04 & {$[1.01-4.13]$} & \\
\hline
\end{tabular}

subjects, 16 were followed by medical staff, 13 by a psychologist and 3 by a psychiatrist. Thirteen adolescents (8.4\%) had an immunosuppression factor: an HIV infection was known in 8 subjects; 3 subjects were chronic ethyl and 2 subjects were diabetic. Subjects affected by the idea of suicide lived in a boarding school in $25.8 \%$ $(n=40)$ of cases, with one parent in $23.9 \%(n=37)$ of cases and with both parents in $50.3 \%(n=78)$ of cases with both parents. Factors associated with suicide attempts were female sex $(\mathrm{p}=0.0107)$, age over 18 years $(\mathrm{p}=0.0177)$, living in a couple $(\mathrm{p}=0.0316)$, underlying immunodeficiency (HIV infection, $\mathrm{p}=0.0059$, sickle cell disease, $p=0.0043$ ) and having a family history of suicides $(p=0.0461)$, (Table 1$)$. The reasons for suicidal ideation were dominated by sentimental difficulties in 41 subjects and academic problems in 35 subjects (Table 2). The means of suicide were revealed by 43 subjects and dominated by drug poisoning (65.1\%) (Table 3 ).

\section{Discussion}

This study shows that the most common reasons for teen ideation and suicide attempt are sentimental and academic difficulties and the most common suicide method used by adolescents is drug intoxication. It identified five factors associated with adolescent suicide attempts in Lomé, including female sex, older age, living in a couple, the existence of underlying immunosuppression, and having family history of suicide.

Among adolescents with suicidal attempts, there was a female predominance with thirty-four cases $(p=0.0107)$ with an odds-ratio of 2.68. In adolescents, suicidal acts are more often than not a means of escaping unbearable tension that the end point of a real desire for death [6]. In the United States, among the 15-19 year olds, $26 \%$ of boys and $41 \%$ of girls thought of suicide in 1997, in Quebec $21 \%$ of

Table 2 Motives for ideas and suicide attempts of adolescents in Lomé

\begin{tabular}{lcr}
\hline Motives & Number of cases $(\mathbf{n})$ & $\%$ \\
\hline Sentimental difficulties & 41 & 26.5 \\
School problems & 35 & 22.6 \\
Health problems & 14 & 9.0 \\
Financial problems & 13 & 8.4 \\
Family problems & 9 & 5.8 \\
Death of a loved one & 7 & 4.5 \\
Loneliness & 4 & 2.6 \\
Unwanted pregnancies & 4 & 2.6 \\
Distaste of life & 3 & 1.9 \\
Absence of parents & 2 & 1.3 \\
Abstained & 23 & 14.8 \\
Total & 155 & 100.0 \\
\hline
\end{tabular}


Table 3 Means of suicide attempts of adolescents in Lomé

\begin{tabular}{lcr}
\hline Means & Number of cases $(\mathbf{n})$ & $\%$ \\
\hline Drug poisoning & 28 & 65.1 \\
Ingestion of caustics & 6 & 14.0 \\
Hanging & 4 & 9.3 \\
Section of veins & 3 & 7.0 \\
Jumping from the top of a building & 2 & 4.6 \\
Total & 43 & 100.0 \\
\hline
\end{tabular}

boys and 37\% of girls [7]. Girls are more likely to attempt suicide; the teenage hospitalization rate for attempted suicide is double that of adolescents, but the suicide rate for boys aged 15-19 is four times higher than for girls in the same group age [5,7]. The observed female predominance of suicides and suicide attempts can be explained by the early pubertal age in girls compared to boys, and the fact that boys have the opportunity to express their dissatisfaction or incomprehension by other means such as than delinquency or aggression, unlike women who have no alternative but to use violence $[1,3]$.

Thirty-one of the forty-six adolescents with suicidal attempts were between the ages of 18 and $19(p=0.0177)$, with an odds-ratio of 2.40. The advanced age of adolescents is a risk factor for suicidal attempts [2]. According to Boeninger et al. [8], the peak of suicidal behavior is around 16 years for girls and then decreases, while it continues to increase in boys up to 19 years of age. Twenty of the fortysix adolescents were married $(\mathrm{p}=0.0316)$, with an oddsratio of 2.25. Couple life would promote the occurrence of suicide attempts. In fact, sentimental difficulties dominate the motivation factors of suicidal ideas and attempts in our study as well as in the Ghanaian study where these difficulties are essentially the infidelity of the partner [9]. Thirteen of the adolescents who attempted a suicidal act had underlying immunodepression, particularly HIV infection, with an odds-ratio of 3.51. Adolescents with underlying immunosuppression would be about four times more likely to attempt suicidal acts compared to healthy adolescents [10]. This finding is explained by a lack of psychosocial care for people living with HIV [10, 11]. Twenty-four adolescents with suicidal attempts, had a family history of suicides $(p=0.0461)$, an odds-ratio of 2.04. Adolescents with a family member who has attempted suicide are more likely to be exposed [12].

\section{Limitations}

The short duration of the study is an insufficiency of our work mainly related to a lack of funding. This lack of funding still explains the fact that the study was conducted in the city of Lomé alone and not on the whole territory that would have allowed to have a larger sample. In addition, it was difficult to verify the sincerity of the information provided by the adolescents surveyed.

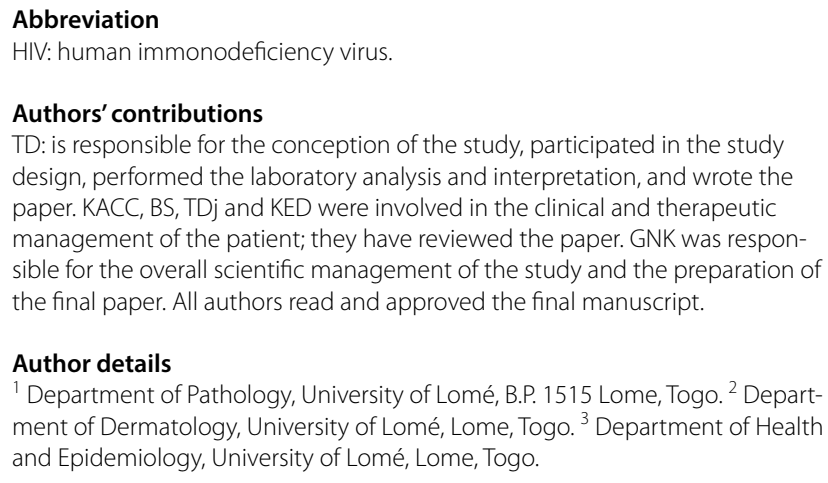
design, performed the laboratory analysis and interpretation, and wrote the paper. KACC, BS, TDj and KED were involved in the clinical and therapeutic management of the patient; they have reviewed the paper. GNK was responsible for the overall scientific management of the study and the preparation of the final paper. All authors read and approved the final manuscript.

\section{Author details}

${ }^{1}$ Department of Pathology, University of Lomé, B.P. 1515 Lome, Togo. ${ }^{2}$ Department of Dermatology, University of Lomé, Lome, Togo. ${ }^{3}$ Department of Health and Epidemiology, University of Lomé, Lome, Togo.

\section{Acknowledgements}

Not applicable.

\section{Competing interests}

The authors declare that they have no competing interests.

Availability of data and materials

All data generated or analyzed during this study are included in this published article.

\section{Consent to publish}

Not applicable.

\section{Ethics approval and consent to participate}

This study received approval from the head of the University of Lomé to be conducted. This study was approved by the head of University of Lomé. University of Lomé (Ref No. 02/2019/FSS/UL). We obtained the approval from the participants. For participants the aged between 15 and 17, we asked for the consent of the parents or the legal guardian or school authorities. The participants gave their written consent, after the verbal explanation. The survey was anonymous and confidential.

\section{Funding}

The authors received no specific funding for this study.

\section{Publisher's Note}

Springer Nature remains neutral with regard to jurisdictional claims in published maps and institutional affiliations.

Received: 13 March 2019 Accepted: 26 March 2019

Published online: 29 March 2019

\section{References}

1. Reinherz H, Tanner J, Berger S, Beardslee W, Fitzmaurice G. Adolescent suicidal ideation as predictive of psychopathology, suicidal behavior, and compromised functioning at age 30. Am J Psychiatry. 2006;163(7):1226-32

2. Hauser M, Galling B. Correll CU Suicidal ideation and suicide attempts in children and adolescents with bipolar disorder: a systematic review of prevalence and incidence rates, correlates, and targeted interventions. Bipolar Disord. 2013;15(5):507-23.

3. Breton J, Tousignant M, Bergeron L, Berthiaume C. Informant-specific correlates of suicidal behavior in a community survey of 12-to 14-years-olds. J Am Acad Child Adolesc Psychiatry. 2002;41:723-30. 
4. Kinyanda E, Kizza R, Levin J, Ndyanabangi S, Abbo C. Adolescent suicidality as seen in rural northeastern Uganda: prevalence and risk factors. Crisis. 2011;32(1):43-51.

5. Mars B, Burrows S, Hjelmeland H, Gunnell D. Suicidal behaviour across the African continent: a review of the literature. BMC Public Health. 2014;14:606.

6. Kennedy SP, Baraff $L$, Suddath RL, Asarnow JR. Emergency department management of suicidal adolescents. Ann Emerg Med. 2004:43(4):452-60.

7. Sakinofsky I, Leenaars AA. Suicide in Canada with special reference to the difference between Canada and the United States. Suicide Life Threat Behav. 1997;27:112-26.

8. Boeninger D, Masyn K, Feldman B, Conger R. Sex difference in developmental trends of suicide ideation, plans, and attempts among European American adolescents. Suicide Life Threat Behav. 2010;40(5):451-64.

9. Osafo J, Akotia CS, Andoh-Arthur J, Quarshie EN. Attempted suicide in Ghana: motivation, stigma, and coping. Death Stud. 2015;39:274-80.

10. Ogundipe OA, Olagunju AT, Adeyemi JD. Suicidal ideation among attendees of a West African HIV clinic. Arch Suicide Res. 2015;19:103-16.

11. Rukundo GZ, Kinyanda E, Mishara B. Clinical correlates of suicidality among individuals with HIV infection and AIDS disease in Mbarara, Uganda. Afr J AIDS Res. 2016:15(3):227-32.

12. Randall JR, Doku D, Wilson ML, Peltzer K. Suicidal behaviour and related risk factors among school-aged youth in the Republic of Benin. PLoS ONE. 2014;9:e88233.
Ready to submit your research? Choose BMC and benefit from:

- fast, convenient online submission

- thorough peer review by experienced researchers in your field

- rapid publication on acceptance

- support for research data, including large and complex data types

- gold Open Access which fosters wider collaboration and increased citations

- maximum visibility for your research: over $100 \mathrm{M}$ website views per year

At BMC, research is always in progress.

Learn more biomedcentral.com/submissions 